\title{
Reporting Comprehensive Income: Reasons for Reporting Choices and Investor Reactions
}

\author{
Bora Turktas ${ }^{1}$, Georgios Georgakopoulos ${ }^{1}$, Ioannis Sotiropoulos ${ }^{2} \&$ Konstantinos Z. Vasileiou ${ }^{3}$ \\ ${ }^{1}$ Amsterdam Business School, University of Amsterdam, Netherlands \\ ${ }^{2}$ Department of Finance and Auditing, TEI of Epirus, Greece \\ ${ }^{3}$ Department of Business Planning \& Information Systems, TEI of Patras, Greece \\ Correspondence: Georgios Georgakopoulos, Amsterdam Business School, University of Amsterdam, Plantage \\ Muidergracht 12, 1018 TV Amsterdam, The Netherlands. Tel: 31-20-525-5260. E-mail: \\ g.georgakopoulos@uva.nl
}

Received: October 31, 2012

Accepted: February 6, $2013 \quad$ Online Published: March 18, 2013

doi:10.5539/ijef.v5n4p1

URL: http://dx.doi.org/10.5539/ijef.v5n4p1

\begin{abstract}
This paper aims to investigate whether the reporting way of comprehensive income is influenced by some factors mentioned by the Positive Accounting Theory and whether the investors value their choice by looking at stock returns (measured in different ways) for firms in the S\&P 350 Europe Index. The research results show that there is no significant association between the reporting choice of firms and the equity-based incentives, job security, volatility and leverage of the firms. Moreover, it was found that the price-earnings ratio and stock returns are associated with reporting choice, but in the opposite direction as expected. The results of a robustness test suggest that there is a significant association between the total compensation of the CEO and the volatility on one side and the reporting choice of firms on the other side. However, these results are not significant in the expected direction, but in the opposite direction.
\end{abstract}

Keywords: comprehensive income disclosure, stock price reactions, volatility, positive accounting theory, European companies

\section{Introduction}

After 1 January 2009 firms implementing International Financial Reporting Standards (IFRSs) have the option to report their comprehensive income in two ways: in a single statement that consists of a statement of comprehensive income or in two separate statements split up in an income statement and a comprehensive income statement (IASB, 2007). Several studies, so far, have dealt with the reporting way of (other) comprehensive income (Bamber et al., 2010; Lee et al., 2006). These studies generally investigate, on one side, the motivations for reporting comprehensive in a certain way and, on the other side, the value relevance of comprehensive income in comparison with net income or other items.

According to efficient market theory, it is expected that there should be no determinants in the choice of reporting comprehensive income, since accounting numbers are not affected. Moreover, there should be no investor reaction to the reporting choice made, because the information hypothesis states that investors capture all known information (strong form of the efficient market theory) and as the same values are disclosed under the same name and no (future) cash flow effect is applicable, no different reaction will be expected.

However, according to Positive Accounting Theory managers can make irrational accounting choices because they can get a higher bonus, avoid debt covenants or avoid political costs (Scott, 2007, p. 287-288). If investors do not capture all information and focus on the bottom line items it could be possible that they overemphasize other comprehensive income items when comprehensive income is disclosed using the more salient single statement option. As other comprehensive income items are generally volatile and transitory, this could lead to investors thinking that the firm performance is more volatile and thus risky (Bamber et al., 2010, p. 99). This could lead to negative stock price reactions, which will be anticipated for by managers.

This research aims to study whether the reporting way of comprehensive income is influenced by some factors stated by Positive Accounting Theory and whether the investors do value their choice by looking at stock returns (measured in different ways). In this light our paper proceeds as follow: In the next section we briefly discuss the 
literature review in relation to comprehensive income, the revised International Accounting Standard 1 (IAS 1), the reporting ways of (other) comprehensive income and the Positive Accounting Theory. We then present our research hypotheses, methodology and data sample. This is followed by our research results. Our paper concludes with a discussion of our findings, limitations of our work and areas for future research.

\section{Literature Review}

\subsection{Comprehensive Income}

An annual statement should include a statement of comprehensive income in order to have complete financial statements (IASB, 2007, p. 12). Three items are important regarding this subject: profit and loss, other comprehensive and comprehensive income. The official definition of profit or loss according to the IASB (2007, p.12) is "profit or loss is the total of income less expenses, excluding the components of other comprehensive income."

Other comprehensive income (OCI) has been defined by the IASB $(2007$, p. 12) as "items of income and expense (including reclassification adjustments) that are not recognized in profit or loss as required or permitted by other IFRSs."

The components of other comprehensive income include (IASB, 2007, p. 12):

(a) Changes in revaluation surplus.

(b) Actuarial gains and losses on defined benefit plans.

(c) Gains and losses arising from translating the financial statements of a foreign operation.

(d) Gains and losses on re-measuring available-for-sale financial assets.

(e) The effective portion of gains and losses on hedging instruments in a cash flow hedge.

Finally, total comprehensive income is the change in equity during a period resulting from transactions and other events, other than those changes resulting from transactions with owners in their capacity, as owners and comprises all components of profit or loss and other comprehensive income (IASB, 2007, p. 12). Thus, the difference between profit or loss and other comprehensive income is stated by the rules of IFRS, which will tell where to place the specific account. The sum of profit or loss and other comprehensive income is the total comprehensive income of the reporting entity for that specific year.

\subsection{Revised IAS 1}

Before the Revised IAS 1 (IASB, 2007), comprehensive income was reported in a statement of profit and loss, and a statement of equity (regarding other comprehensive income).

However, a statement of comprehensive income was not applicable, which could present the total changes in income directly in one statement or two consecutive statements in an income statement format. With the revised IAS 1 (IASB, 2007), firms have two options regarding the disclosure of comprehensive income:

1) In a single statement of comprehensive income.

2) In two separate statements; being an income statement and a statement of comprehensive income which includes other comprehensive income, with the sum of non-owner movements carried to the statement of changes in equity.

However, in May 2010, the IASB published ED/2010/: Presentation of Items of Other Comprehensive Income (proposed amendments to IAS 1) (Deloitte, 2010, p. 1). The Exposure Draft proposes the following:

$\checkmark$ Presentation of profit or loss and OCI as separate components in a single financial statement.

$\checkmark$ Separate presentation in OCI of items that will be reclassified to profit or loss in a subsequent period.

Especially, the first proposition is important in the context of this paper, because it eliminates the choice option for companies using IFRS and mandates one way of reporting comprehensive income. According to the IASB, the following benefits will be the case when a single statement is used (Deloitte, 2010, p. 2):

$\checkmark$ All non-owner changes in equity would be presented in the same statement.

$\checkmark$ Comparability would be improved as the other presentation option currently available under IAS 1 would be eliminated.

$\checkmark$ A clear distinction would be made between profit or loss and items in other comprehensive income, thus preserving the importance of profit or loss and at the same time highlighting the importance of the gains or losses as a result of other changes in non-owner equity. 
$\checkmark$ Full transparency of items included in OCI, thus highlighting to users the items in OCI that will never be recycled into profit or loss.

In the 2010 comment letters responding to the Exposure Draft, the following concerns have been raised by respondents about the proposals. (Henry, 2011, p. 86):

$\checkmark$ When a single statement format will be used, net income would be de-emphasized, being seen as a subtotal rather than a bottom line.

$\checkmark$ Confusions would arise about the number to use for Earnings Per Share (EPS) calculations.

$\checkmark \quad$ Items of other comprehensive income would be overemphasized.

However, on 16 June 2011 the IASB issued the amendments to IAS 1 and the two choices for reporting comprehensive income were kept intact; a mandatory single disclosure format for comprehensive income was not included. Thus, companies using IFRS are still left to choose to report in a single format or two different statements.

Another important aspect of the ruling regarding the disclosure of comprehensive income is the convergence process and specifically, the changes made by the Financial Accounting Standards Board (FASB). Before the changes in the Accounting Standards Update in the second quarter of 2011 (effective after 15 December 2011), firms implementing US GAAP had three options for reporting their comprehensive income; the first two options are similar to the current standard of the IASB (performance reporting in a single statement or two separate statements) and the other option was to report comprehensive income within the statement of stockholder's equity. The last option was deleted and therefore, the presentation possibilities of comprehensive income are similar to the options of the IASB now, although there are still calculation differences. There are two reasons for the FASB to make this change (Henry, 2011, p. 85):

$\checkmark$ This will increase the prominence of items reported in other comprehensive income.

$\checkmark$ This facilitates the convergence between US GAAP and IFRS (Henry, 2011, p. 85).

\subsection{Prior Literature on the Reporting Way of (Other) Comprehensive Income}

There have been several studies covering the reporting location/way of (other) comprehensive income (Bamber et al., 2010; Lee et al., 2006), inquiring the motivations for reporting comprehensive in a certain way and the value relevance of comprehensive income in comparison with net income or other items.

Bamber et al. (2010), who investigated the association between manager's job security and manager's equity-based compensation, and the reporting location, found that managers with more equity-based incentives and less job security are more likely to avoid performance reporting by reporting in a statement of equity. This is because reporting in a statement format increases the salience of the often volatile other comprehensive income, which conduces investors to deem the income of the firm as more volatile. Volatile income will lead to a more risky profile of the firm, which leads to a negative investor reaction and lower stock prices. As managers with less job security and more equity-based compensation have more to suffer from stock price declines, they choose to report in a statement of equity.

Lee et al. (2006) also studied the motivations for the reporting location/way of comprehensive income and they found that insurers who report comprehensive income in a statement of equity are more likely to smooth earnings by cherry-picking realized gains and losses on available-for-sale (AFS) securities. This is because they think that reporting other comprehensive income (and thus realized gains and losses on Available-For-Sale (AFS) securities) in a statement of equity is a less salient way of reporting and attracts less attention from investors, thus the earnings management engaged by the manager is less salient and the chance that an investor captures this is smaller.

Hirst and Hopkins (2008) used an experiment with buy-side financial analysts and asked them to value firms that have earnings management and no earnings management and they manipulated the experiment by reporting comprehensive income in two different formats (performance reporting and reporting in a statement of equity). They found that a clear display of comprehensive income and its components in a separate statement of performance (performance reporting) made earnings management more transparent and resulted in statistically equal stock price judgments for the earnings management and non-earnings management firms. Thus, buy-side analysts could detect earnings management easier when comprehensive reporting was reported in a performance reporting format, which lead to better stock price judgments and an efficient market. An experiment by Maines and McDaniel (2000) reached to similar results for non-experienced investors (students). This also provides support for the decision of the FASB and IASB to mandate performance reporting and delete the option of 
reporting in an equity statement.

The location/reporting way of comprehensive income does not only affect the perception of users, but as well, the behavior of managers/firms. Hunton et al. (2006) showed that greater transparency in comprehensive income reporting also reduces the likelihood that managers will engage in earnings management.

Other important research about the reporting way of comprehensive income focused on the value relevance of comprehensive income and/or its components. Goncharov and Hodgson (2011) found that net income is more value relevant than comprehensive income for European companies. Cheng et al. (1993) and Dhaliwal et al. (1999) also reached to the same conclusion. Cahan et al. (2000) found that disclosure of other comprehensive income in the statement of equity is less value relevant than comprehensive income.

Chambers et al (2007) detected contradictory evidence and showed that investors, on average, price OCI, when it is reported, in the most predominant location: the statement of changes in shareholders' equity. Other contradictory evidence comes from Kanagaretnam et al. (2009), who found that comprehensive income is more value relevant compared to net income.

\subsection{Positive Accounting Theory}

Positive Accounting Theory (PAT) is a theory that tries to predict real-world events. It is concerned with predicting such actions as the choices of accounting policies by firm managers and how managers will respond to proposed accounting standards (Scott, 2007, p. 284). It argues that a set of accounting policies (in the context the disclosure option of comprehensive income) opens up the possibility of opportunistic behavior ex post. PAT assumes that managers are rational and will choose accounting policies in their own best interest if they are able to do so. Managers put their own interest over the interest of the firm and will try to maximize their own expected utility instead of maximizing firm profits (Scott, 2007, p. 285). While normative theories, such as decision theory, concentrate on what managers should do, positive theories such as PAT try to predict what managers will do.

Watts and Zimmerman (1986) have set up three hypotheses than can be used to predict managerial actions according to PAT:

1) The bonus plan hypothesis: This hypothesis suggests that other things being equal, managers of firms with bonus plans are more likely to choose accounting procedures that will lift up their remuneration, mainly by bringing future earnings to the current period. One of the other predictions of this hypothesis is that managers will choose accounting procedures that will lead to smooth earnings instead of volatile earnings (Scott, 2007, p. 287).

2) The debt covenant hypothesis: This hypothesis suggests that if a firm is closer to violating debt covenants, the manager is more likely to shift reported earnings from future periods to the current period, because this will decrease the chance of technical default and thus decrease the chance that the manager's actions will be constrained by covenant violations. Again, managers could also choose for accounting procedures that will lead to smooth earnings instead of volatile earnings (Scott, 2007, p. 288).

3) The political cost hypothesis: If a firm faces probable high political costs because of high profitability the managers could have a tendency to defer earnings from current periods to future periods. For example, very high reported earnings can lead to higher taxes, which will lead to higher income for governments, but higher taxes for firms.

\section{Hypotheses Development}

As mentioned before, this research aims to study whether the reporting way of comprehensive income is influenced by some factors according to the Positive Accounting Theory and whether investors do value their choice by looking at stock returns (measured in different ways).

Firstly, the relationship between a certain disclosure format and a higher volatility will be examined. In general, comprehensive income items are regarded to be more volatile than net income. This is because the items in other comprehensive income are mainly based on developments in the market (for example, market interest fluctuations affect actuarial gains/losses and gains/losses from available-for-sale securities), while the net income of a firm does not fluctuate very much in general, especially, compared to comprehensive income. Bamber et al. (2010) confirmed that other comprehensive income is more volatile because unrealized gains and losses, part of other comprehensive income, come from uncontrollable and volatile market forces and are, therefore, not persistent.

Henry (2011, p. 88) has examined the volatility of comprehensive income relative to the volatility of net income 
by looking at the standard deviations of the two numbers for the S\&P 500 companies from fiscal year 2005 until $2010(n=2538)$. The results show that for the half of the companies the standard deviation of comprehensive income is 13 percent higher than the standard deviation of net income. At the maximum, the standard deviation of comprehensive income is 11 times higher than the standard deviation of net income (Henry, 2011, p. 88).

For the sample of our study (S\&P Europe 350 companies, $n=246$; see section 4.2) we found a median of 1.54 , which means that for the half of the companies the standard deviation of comprehensive income is 54 percent higher than the standard deviation of net income. At the maximum, the standard deviation of comprehensive income is 9.54 times higher than the standard deviation of net income.

The next step is to compare the single-statement reporting method with the separate statements reporting method. Since items of other comprehensive income would be overemphasized and net income would be de-emphasized in a single statement and other comprehensive items are more volatile in general, we would expect that the total performance of the firm reporting in a single statement would be regarded as more volatile.

Secondly, the relationship between a higher volatility and a negative investor price reaction will be investigated. Farrely et al. (1985) and Koonce et al. (1998) showed, with laboratory experiments, that both professional and non-professional investors associate variability in earnings with higher firm risk. According to Koonce et al. (1998) financial statement users also perceive uncontrollable items as increasing risk, so it could be expected that the uncontrollable nature of other comprehensive income items should lead to higher perceived risk in the eyes of investors. Finally, Graham et al. (2005, p. 49) showed in their research, based on interviews with CFOs, that CFOs believe that the stock market does value earnings predictability. CFOs believe that their P/E ratio would drop if their earnings path becomes more volatile, even if cash volatility stays the same. They, also, argued that investors demand a lower risk premium if the earnings path is steady. They thought this is because the market becomes more skeptical about underlying cash flows when earnings are more volatile and it regards firms with more volatile earnings (ceteris paribus) as more risky, which is reflected in a lower stock price. This is consistent with behavioral research which supports that managers are concerned that a more salient performance reporting could hurt the firm's stock price (Hunton et al., 2006; Maines and McDaniel, 2000.

Therefore, we hypothesize that firms with a higher volatility would choose to report their comprehensive income in separate statements and avoid using a single statement format.

H1a: Firms that have a higher volatility of other comprehensive income avoid reporting their comprehensive income in a more salient single statement format.

Managers should avoid reporting in a single statement format, because it leads to higher perceived volatility, higher risk and a lower stock price.

It is expected that managers could face greater risk of losing their jobs when they receive unfavorable performance evaluations, which could include poor stock price performance. These managers have a lower job security and have therefore more to lose from a more volatile performance leading to a lower stock price.

Consistent with Bamber et al. (2010), we hypothesize that managers with lower job security would choose to report their comprehensive income in separate statements and avoid using a single statement format.

H1b: Firms in which the CEO has lower job security would avoid reporting their comprehensive income in a more salient single statement format.

It is expected that managers with more powerful equity-based incentives have more to lose from lower stock prices and would prefer reporting methods that lower perceived volatility of form performance (Goel and Thakor, 2003). Maines and McDaniel (2000) also found that investors who evaluate manager's performance penalize managers for volatility in comprehensive income, only when comprehensive income appears in a salient statement. Consistent with Bamber et al. (2010), we hypothesize that firms in which the CEO has more equity-based incentives would choose to report their comprehensive income in separate statements and avoid using a single statement format.

H1c: Firms in which the CEO has higher equity-based incentives avoid reporting their comprehensive income in a more salient single statement format.

According to Graham et al. (2005), managers of more levered firms are more concerned with smoothing earnings to minimize perceived risk of the firm. Therefore, managers of companies with a relative high leverage would be more likely to avoid reporting in the more salient single statement format to reduce the perceived volatility and risk (Bamber et al., 2010, p. 112). Therefore, we hypothesize that firms with a higher leverage would choose to report their comprehensive income in separate statements and avoid using a single statement 
format.

H1d: Firms with a higher leverage would avoid reporting their comprehensive income in a more salient single statement format.

It has been argued that comprehensive income shown in a single statement of comprehensive income will lead to earnings looking more volatile to investors. Graham et al. (2005, p. 49) showed in their research, based on interviews with CFOs, that CFOs believe that the stock market does value earnings predictability. CFOs believe that their P/E multiple would drop if their earnings path becomes more volatile, even if cash volatility stays the same. Moreover, investors demand a lower risk premium if the earnings path is steady. This is because the market becomes more skeptical about underlying cash flows when earnings are more volatile and regard firms with more volatile earnings (ceteris paribus) as more risky, which is reflected in a lower stock price. Therefore, we hypothesize that firms that report in a single statement format will face a negative investor reaction due to higher perceived volatility/risk and have a lower stock price.

H2: Firms that report their comprehensive income in a more salient single statement format have a lower stock price.

\section{Methodology and Data Collection}

\subsection{Methodology}

Two regression models are used to answer to research hypotheses. In the first regression model, which deals with the first four hypotheses, the dependent variable will be the reporting choice and the independent variables will be the key variables and control variables. The definitions of all the variables included in both models employed in our research are shown in Table 1. The first regression model is similar to the model of Bamber et al. (2010, p. 111). The only difference with their model lies in the control variables. Because the items of other comprehensive income under US GAAP and IFRS differ, the definition of the control variables has been changed and some control variables have been added. PENSION is now the actuarial gains and losses on defined benefit pension plans instead of the unrealized gains and losses resulting from changes in the minimum pension obligation. Moreover, the variables REV (changes in revaluation surplus) and CASHFL (value of the effective portion of gains and losses on hedging instruments in a cash flow hedge) have been added, because these items exists under IFRS, but did not exist under US GAAP.

Other comprehensive income items are added because: a) Comment letters to FAS 130 show that investors have concerns about the volatility of comprehensive income and b) Chambers et al. (2007) and Lee et al. (2006) found that other comprehensive income items are value relevant. Lee et al. (2006) also concluded that size and auditor choice are value relevant and therefore these are also included as control variables.

Thus, the first regression model is:

$$
\begin{gathered}
C H O I C E=\beta_{0}+\beta_{1} \text { EQUITYCOMP }+\beta_{2} \text { JSECURITY }+\beta_{3} \text { VOLATILITY }+\beta_{4} L E V E R A G E+\beta_{5} A F S S E C+\beta_{6} \\
\text { PENSION }+\beta_{7} \text { FORCUR }+\beta_{8} R E V+\beta_{9} \text { CASHFL }+\beta_{10} \text { DISCQUAL }+\beta_{11} L O G S I Z E+\beta_{12} A U D+\varepsilon
\end{gathered}
$$

Job security (JSECURITY) is measured in the same way as Bamber et al. (2010). Several studies showed that CEO-chair duality (Desai et al., 2004; Goyal and Park, 2002; Lucier et al., 2004) has an influence on CEO turnover and CEOs that chair the board enjoy lower turnover. Weisback (1988) and Huson et al. (2001) show that boards dominated by insiders/outsiders are associated with lower/higher CEO turnover. Therefore, consistent with Bamber et al. (2010), the variable JSECURITY is based on these two factors and is defined as follows:

$$
\text { JSECURITY }=\text { CHAIRMAN }+ \text { DIRECTORS }
$$

Where:

CHAIRMAN $=1$ if the CEO also chairs the board of directors and 0 otherwise and

DIRECTORS $=1$ if the percentage of outside directors on the firm's board is smaller than the sample median and 0 otherwise.

Disclosure quality (DISCQUAL) is a common factor derived from analyst following (ANFOR), bid-ask spreads (BIDASK) and closely held shares (CLSHR). This variable is used as a control variable because Lee et al. (2006) mentioned that firms with a higher disclosure quality are more likely to use a more salient reporting method. Finally, the auditor choice (AUD) is used, because Lee et al. (2006) noted that there is a link between disclosure quality and the auditor of the company. 
Table 1. Explanation of variables

\begin{tabular}{|c|c|}
\hline Variable & Explanation \\
\hline AFSSEC & $\begin{array}{l}1 \text { if the gains or losses from available-for-sales securities scaled by total assets in the comprehensive } \\
\text { income year (2010) exceeds the sample median and } 0 \text { otherwise, manually collected from financial } \\
\text { statements }\end{array}$ \\
\hline ANFOR & $\begin{array}{l}\text { The number of forecasts made by analysts for the Earnings Per Share of the company for the year } 2010 \\
\text { in the } \mathrm{I} / \mathrm{B} / \mathrm{E} / \mathrm{S} \text { database }\end{array}$ \\
\hline AUD & $\begin{array}{l}\text { Auditor of the financial statements of the companies, with a } 1 \text { if the auditor is KPMG of PWC and } 0 \\
\text { otherwise, manually collected from financial statements }\end{array}$ \\
\hline BIDASK & $\begin{array}{l}\text { Bid-ask spread calculated by the difference in the bid price (PB) and ask price (PA) of the company's } \\
\text { share divided by the corresponding daily closing price (P), averaged over the month December 2010, } \\
\text { collected from Datastream }\end{array}$ \\
\hline CASHFL & $\begin{array}{l}1 \text { if the gains or losses from cash flow hedges scaled by total assets in the comprehensive income year } \\
\text { (2010) exceeds the median sample and } 0 \text { otherwise, manually collected from financial statements }\end{array}$ \\
\hline CHOICE & $\begin{array}{l}\text { Way of reporting comprehensive income, with a } 1 \text { for firms that report in separate statements and } 0 \text { for } \\
\text { firms that report in a single statement, manually collected from financial statements }\end{array}$ \\
\hline CI & $\begin{array}{l}\text { Total comprehensive income for the comprehensive income year (2010) scaled by total assets, manually } \\
\text { collected. }\end{array}$ \\
\hline CLSHR & $\begin{array}{l}\text { Closely held shares scaled by total outstanding shares (WC08021) in the comprehensive income year } \\
\text { (2010), collected from Datastream }\end{array}$ \\
\hline DISCQUAL & Disclosure quality factor extracted by closely held shares, bid-ask spreads and analysts following \\
\hline EQUITYCOMP & $\begin{array}{l}\text { Equity based part of the CEO compensation/total compensation of the CEO excluding pension costs, } \\
\text { manually collected from financial statements }\end{array}$ \\
\hline FORCUR & $\begin{array}{l}1 \text { if the foreign currency translation scaled by total assets in the comprehensive income year (2010) } \\
\text { exceeds the sample median and } 0 \text { otherwise, manually collected from financial statements }\end{array}$ \\
\hline JSECURITY & Job security of the CEO (see explanation), manually collected from financial statements \\
\hline LEVERAGE & Total non-current liabilities divided by total assets, manually collected from financial statements \\
\hline LOGSIZE & Log of the common shares (WC08001) of the company, collected from Datastream \\
\hline NI & $\begin{array}{l}\text { Net income scaled by the total assets of the company for the comprehensive income year (2010), } \\
\text { manually collected. }\end{array}$ \\
\hline OCI & $\begin{array}{l}\text { Other comprehensive income scaled by total assets, calculated as the difference between net income } \\
\text { scaled by total assets and comprehensive income scaled by total assets. }\end{array}$ \\
\hline PBOOK & $\begin{array}{l}\text { Price-to-book value ratio (P/WC05476) of the company for the comprehensive income year (2010), } \\
\text { collected from Datastream }\end{array}$ \\
\hline PEARN & $\begin{array}{l}\text { Price-to-earnings ratio (P/EPS) of the company for the comprehensive income year (2010), collected } \\
\text { from Datastream }\end{array}$ \\
\hline PENSION & $\begin{array}{l}1 \text { if the actuarial gains or losses scaled by total assets in the comprehensive income year (2010) exceeds } \\
\text { the sample median and } 0 \text { otherwise, manually collected from financial statements }\end{array}$ \\
\hline PSALES & $\begin{array}{l}\text { Price-to-sales ratio (P/WC01001) of the company for the comprehensive income year (2010), collected } \\
\text { from Datastream }\end{array}$ \\
\hline RETURN & Stock return of the company for the comprehensive income year (2010), collected from Datastream \\
\hline REV & $\begin{array}{l}1 \text { if the revaluation surplus scaled by total assets in the comprehensive income year (2010) exceeds the } \\
\text { sample median and } 0 \text { otherwise, manually collected from financial statements }\end{array}$ \\
\hline TOTALCOMP & $\begin{array}{l}\text { Total compensation of the CEO excluding pension benefits, scaled by total assets, manually collected } \\
\text { from financial statements }\end{array}$ \\
\hline VOLATILITY & $\begin{array}{l}\text { Volatility of other comprehensive income, calculated by dividing the standard deviation of } \\
\text { comprehensive income scaled by total assets with the standard deviation of net income scaled by total } \\
\text { assets, measured over the comprehensive income year }(2010) \text { and the two prior years, manually collected } \\
\text { from financial statements }\end{array}$ \\
\hline
\end{tabular}

PWC and KMPG are used as specialist auditor, because they audit 62 percent of the sample of 246 firms (see bellow section 4.2, Sample of the study).

In the second regression, employed for the second hypothesis, stock returns are the dependent variable and the reporting choice serves with other key/control variables as the independent variables. 


$$
\begin{gathered}
R E T=\beta_{0}+\beta_{1} C H O I C E+\beta_{2} C I+\beta_{3} N I+\beta_{4} O C I+\beta_{5} \text { VOLATILITY }+\beta_{6} L E V E R A G E+\beta_{7} A F S S E C+\beta_{8} P E N S I O N+\beta_{9} F O R C \\
U R+\beta_{10} R E V+\beta_{11} C A S H F L+\beta_{12} D I S C Q U A L+\beta_{13} \text { LOGSIZE }+\beta_{14} A U D+\varepsilon
\end{gathered}
$$

The dependent variable is measured by using several proxies to increase the reliability. First of all, by using the traditional way as used in finance and also as used by Dechow (1994), namely the difference between the stock price relative to last year plus the dividend payout divided by last year's stock price. And secondly, by using different ratio's, namely the price-to-book value, the price-to-earnings ratio the price-to-sales ratio. By using several ratios different effects on stock prices such as higher earnings and higher sales are filtered out and controlled against, this increases the reliability of our results.

Moreover, three extra control variables are added. Other comprehensive income scaled by total assets (OCI) is added, because Chambers et al. (2007) and Lee et al. (2006) found evidence that other comprehensive income items are value relevant for investors. Net income scaled by total assets (NI) is added, because Goncharov and Hodgson (2011) found evidence that net income is more value relevant than comprehensive income for investors. Finally, total comprehensive income scaled by total assets (CI) is added, because Kanagaretnam, Mathieu and Shehata (2009) noticed that contradictory evidence and showed that comprehensive income is more value relevant compared to net income.

The variables EQUITYCOMP, VOLATILITY, LEVERAGE and DISCQUAL have been winsorized at $5 \%$ and $95 \%$ for the first regression. For the second regression, the variables VOLATILITY, LEVERAGE, DISCQUAL, RETURN, PBOOK, PSALES, PEARN, CI, NI and OCI have been winsorized at $5 \%$ and $95 \%$.

The results of the factor analysis to create DISCQUAL are shown in Table 2. All firms that are included in the initial sample (see section 4.2) have been used. After filtering the companies with incomplete data 329 firms/observations are left. The factor analysis has been conducted over these firms. Panel A shows descriptive statistics for the three variables. Panel B shows the results of a Spearman correlation for the three variables. The only significant relation is between analyst forecasts and bid-ask spreads; there is a negative correlation between these two variables. Panel $\mathrm{C}$ shows the results and the factor loadings of the conducted factor analysis. BIDASK has the greatest coefficient of all the variables and is positively related with the DISCQUAL factor. CLSHR is also positively related with the DISCQUAL factor, while ANFOR is negatively related. The DISCQUAL factor explains $39.79 \%$ of the total variance.

\begin{tabular}{|c|c|c|c|c|}
\hline \multicolumn{5}{|c|}{ Panel A: Descriptive statistics of disclosure quality proxies } \\
\hline Variable & Minimum & Maximum & Mean & Standard Deviation \\
\hline BIDASK & 0.0002 & 0.0063 & 0.0014 & 0.0012 \\
\hline CLSHR & 0.0100 & 86.9000 & 22.0320 & 21.2748 \\
\hline ANFOR & 0 & 609 & 133.7660 & 71.3490 \\
\hline \multicolumn{5}{|c|}{ Panel B: Spearman correlation of disclosure quality proxies } \\
\hline Variable & BIDASK & CLSHR & ANFOR & \\
\hline BIDASK & 1 & & & \\
\hline CLSHR & 0.0642 & 1 & & \\
\hline p-value & 0.24552 & & & \\
\hline ANFOR & $-0.3143 *$ & 0.0397 & 1 & \\
\hline p-value & $<0.0001$ & 0.4729 & & \\
\hline \multicolumn{5}{|c|}{ Panel C: Factor loadings } \\
\hline Variable & DISCQUAL & & & \\
\hline BIDASK & 0.7179 & & & \\
\hline CLSHR & 0.2567 & & & \\
\hline ANFOR & -0.6470 & & & \\
\hline Variance explained & $39.79 \%$ & & & \\
\hline
\end{tabular}

Table 2. Results of factor analysis to create DISCQUAL $(\mathrm{n}=329)$

A robustness test has been performed, because for a big part of the sample (58 companies) there was no information disclosed in the financial statements about the equity-based part of the CEO compensation. Therefore, instead of using the equity-based part of the CEO compensation, the total compensation of the CEO (excluding pension benefits) scaled by total assets is used as a proxy. This gives a sample of 165 firms, instead of the 107 firms that is used in the first regression. The same model as in the first regression is used, since only 
EQUITYCOMP is replaced by TOTALCOMP. The variables TOTALCOMP, VOLATILITY, LEVERAGE and DISCQUAL have been winsorized at $5 \%$ and $95 \%$. The model is as follows:

$$
\begin{gathered}
\text { CHOICE }=\beta_{0}+\beta_{1} \text { TOTALCOMP }+\beta_{2} \text { JSECURITY }+\beta_{3} \text { VOLATILITY }+\beta_{4} L E V E R A G E+\beta_{5} A F S S E C+\beta_{6} \\
\text { PENSION }+\beta_{7} \text { FORCUR }+\beta_{8} \text { REV }+\beta_{9} \text { CASHFL }+\beta_{10} \text { DISCQUAL }+\beta_{11} L O G S I Z E+\beta_{12} A U D+\varepsilon
\end{gathered}
$$

\subsection{Sample of the Study}

The sample of the study consists of the firms from the S\&P 350 Europe Index (Datastream code: SPEU350). S\&P 350 Europe Index is an equity index drawn from 17 major European markets, covering approximately 70\% of the region's market capitalization (S\&P, 2012). This provides a representative sample for European companies, as it represents a big part of the market capitalization of European companies. The data used are from fiscal year 2010. There are three reasons for this: First of all, the revised IAS 1 ruling is implemented after 1 January 2009, so this research could only focus on a later date. Secondly, fiscal year 2010 has been chosen instead of fiscal year 2009 to overcome problems with fiscal years not corresponding with calendar years. Thirdly, firms would have a one-year experience year and more know-how in fiscal year 2010, so fiscal year 2010 would be a better choice than the initial fiscal year 2009.

The sample composition is shown in Table 3. First of all, (the same) companies with more than one type of share or are dropped, because only consolidated reporting information is used. Secondly, companies in the financial sector are dropped, because the financial sector has its own rulings and incentives. Thirdly, since this research concentrates on the revised IAS 1 ruling, companies that do not use IFRS as reporting standards are dropped. Moreover, companies with missing data on disclosure quality, size or returns are dropped. Lastly, for the first regression, firms with missing data on (equity-based) CEO compensation and firms with a one-tier board system are dropped. Firms with a one-tier board system are dropped, because it does not correspond with the proxy used to measure the job security of the manager.

Table 3. Sample selection

\begin{tabular}{ll}
\hline All shares listed on the S\&P Europe 350 & 365 \\
\hline - companies with more than 1 type of share & -26 \\
- companies in the financial sector & -69 \\
- companies that do not use IFRS & -6 \\
- companies with no information on disclosure quality & -9 \\
- companies with no information on size & -4 \\
- companies with no information on returns & -3 \\
\hline Sample size for regression 2 & 246 \\
\hline - companies that do not have a one-tier board system & -47 \\
- companies with no information on total CEO compensation & -34 \\
- companies with no information on equity based compensation of CEO & -58 \\
\hline Sample size for regression 1 & 107 \\
\hline
\end{tabular}

Our final sample for the second regression consists of 246 firms. When the missing data on (equity-based) CEO compensation and companies with a one-tier board system are dropped, a final sample of 107 firms for the first regression is left.

\section{Research Results}

\subsection{First Regression}

\subsubsection{Descriptive Statistics}

Table 4 shows the descriptive statistics for the first regression, used for hypothesis 1a-1d. Panel A shows the composition of the reporting choice in the sample. From the 107 companies, 96 (89.72\%) report their comprehensive income in two separate statements. Only 11 companies (10.28\%) report comprehensive income in a single statement format. The results are in line with Bamber et al. (2010), who found that 19 percent reported in a more salient performance statement, while 81 percent reported in a statement of equity. The mean of EQUITYCOMP is 0.2630 , which means that on average, $26.30 \%$ of the compensation of the CEO's consist of equity-based incentives. The mean of VOLATILITY is 3.0855 , which means that the volatility of comprehensive income is on average 3 times higher than the volatility of net income. 
Table 4. Descriptive statistics for regression $1(\mathrm{n}=107)$

\begin{tabular}{|c|c|c|c|c|c|}
\hline \multicolumn{6}{|c|}{ Panel A: Sample composition } \\
\hline \multicolumn{2}{|l|}{ Method } & \multicolumn{2}{|c|}{ Number of observations } & \multicolumn{2}{|c|}{ Percentage } \\
\hline \multicolumn{2}{|c|}{ Single statement reporting } & \multicolumn{2}{|l|}{11} & \multicolumn{2}{|l|}{$10.28 \%$} \\
\hline \multicolumn{2}{|c|}{ Separate statements reporting } & \multicolumn{2}{|l|}{96} & \multicolumn{2}{|l|}{$89.72 \%$} \\
\hline \multicolumn{6}{|c|}{ Panel B: Summary statistics } \\
\hline Variable & $1^{\text {st }}$ Quartile & Median & $3^{\text {rd }}$ Quartile & Mean & Standard Deviation \\
\hline CHOICE & 1 & 1 & 1 & 0.8972 & 0.3051 \\
\hline EQUITYCOMP & 0.0645 & 0.2748 & 0.3881 & 0.2630 & 0.2015 \\
\hline JSECURITY & 0 & 1 & 1 & 0.6729 & 0.6555 \\
\hline VOLATILITY & 1.0466 & 1.7673 & 3.2286 & 3.0855 & 3.2353 \\
\hline LEVERAGE & 0.1668 & 0.2814 & 0.3521 & 0.2755 & 0.1301 \\
\hline AFSSEC & 0 & 0 & 1 & 0.3832 & 0.4884 \\
\hline PENSION & 0 & 0 & 0 & 0.3990 & 0.1592 \\
\hline FORCUR & 0 & 0 & 1 & 0.4953 & 0.2523 \\
\hline REV & 0 & 0 & 0 & 0.0374 & 0.1906 \\
\hline CASHFL & 0 & 0 & 1 & 0.3738 & 0.4861 \\
\hline DISCQUAL & -0.6982 & -0.2359 & 0.1888 & -0.2954 & 0.7287 \\
\hline LOGSIZE & 6.7493 & 7.1051 & 7.6433 & 7.1993 & 0.6022 \\
\hline AUD & 0 & 1 & 1 & 0.6449 & 0.4808 \\
\hline
\end{tabular}

Table 5 presents the results of a Spearman correlation test between the variables in the first regression and the corresponding p-values. First of all, there is a significant correlation between AFSSEC and CHOICE. The positive correlation shows that firms with higher gains/losses from available-for-sale securities tend to report in the less salient separate statements method. This is in line with the results of Lee et al. (2006), who concluded that cherry-picking firms (managing earnings through realized gains and losses on securities) have a tendency to report in the less salient statement of equity instead of the more salient performance statement. There is also a positive relationship between AFSSEC and VOLATILITY, which means that firms with a relative more volatile comprehensive income have higher gains/losses from available-for-sale securities. This could be expected, because other comprehensive items are in general more volatile, as was explained before. Another remarkable significant correlation is between DISCQUAL and JSECURITY. It shows that firms with a higher disclosure quality, they also provide a higher job security. This could be the case, because firms that are doing well and where the CEO has a high job security could have fewer incentives to report less or report in a lower quality. Therefore, they could report in a higher quality and therefore could have more analysts following, for example. The correlation between LOGSIZE and AFSSEC is also significant and positive. This could be, because bigger firms should have more resources to invest in available-for-sale securities and could also have a higher expertise to make gains on these securities.

Table 5. Correlation of variables in regression $1 * * * *$

\begin{tabular}{|c|c|c|c|c|c|c|c|c|c|c|c|c|c|}
\hline Variable & CHOICE & EQUITYCOMP & JSECURITY & VOLATILITY & LEVERAGE & AFSSEC & PENSION & FORCUR & REV & CASHFL & DISCQUAL & LOGSIZE & AUD \\
\hline CHOICE & 1 & 0.0316 & -0.0871 & -0.0144 & 0.0842 & $0.2035^{* *}$ & 0.0123 & 0.1507 & 0.0667 & $-0.1837 * * *$ & -0.0259 & 0.0309 & -0.1226 \\
\hline $\mathrm{p}$-value & 0 & 0.74648 & 0.37204 & 0.88241 & 0.38791 & 0.03568 & 0.89968 & 0.12115 & 0.49418 & 0.05835 & 0.79078 & 0.75175 & 0.20805 \\
\hline EQUITYCOMP & 0.0316 & 1 & -0.0744 & -0.1063 & $-0.1867 * * *$ & $0.1681 * * *$ & 0.0226 & 0.0499 & 0.0481 & -0.0830 & -0.1094 & -0.0456 & $0.2537^{*}$ \\
\hline p-value & 0.746475 & 0 & 0.44571 & 0.27548 & 0.05429 & 0.08355 & 0.81693 & 0.60911 & 0.62197 & 0.39461 & 0.26155 & 0.64070 & 0.00851 \\
\hline JSECURITY & -0.0871 & -0.0744 & 1 & $0.1648 * * *$ & -0.0450 & -0.0709 & 0.0741 & 0.1094 & 0.0926 & 0.1913 & 0.1999 & -0.0366 & 0.0538 \\
\hline p-value & 0.37204 & 0.445711 & 0 & 0.08977 & 0.64495 & 0.46742 & 0.44720 & 0.26135 & 0.34213 & 0.04858 & 0.03909 & 0.70757 & 0.58115 \\
\hline VOLATILITY & -0.0144 & -0.1063 & 0.1648 & 1 & 0.2084 & $0.2337^{* *}$ & 0.0842 & 0.0124 & -0.1532 & -0.0497 & -0.0190 & 0.0915 & -0.0098 \\
\hline $\mathrm{p}$-value & 0.88241 & 0.27548 & 0.08977 & 0 & 0.03144 & 0.01556 & 0.38794 & 0.89889 & 0.11519 & 0.61046 & 0.84540 & 0.34809 & 0.92009 \\
\hline LEVERAGE & 0.0842 & $-0.1867 * * *$ & -0.0450 & $0.2084 * *$ & 1 & $0.1637^{* * *}$ & -0.1497 & -0.0490 & 0.0327 & 0.0788 & 0.0385 & 0.1248 & $-0.2476^{* *}$ \\
\hline p-value & 0.38791 & 0.05429 & 0.64495 & 0.03144 & 0 & 0.09197 & 0.12362 & 0.61550 & 0.73765 & 0.41908 & 0.69349 & 0.19999 & 0.01030 \\
\hline AFSSEC & $0.2035^{* *}$ & $0.1681^{* * *}$ & -0.0709 & $0.2337 * *$ & $0.1637^{* * *}$ & 1 & -0.0991 & 0.1035 & 0.0474 & $-0.1719 * * *$ & $-0.1734 * * *$ & $0.2197 * *$ & 0.1430 \\
\hline p-value & 0.03568 & 0.08355 & 0.46742 & 0.01556 & 0.09197 & 0 & 0.30949 & 0.28828 & 0.62759 & 0.07664 & 0.07418 & 0.02316 & 0.14145 \\
\hline PENSION & 0.0123 & 0.0226 & 0.0741 & 0.0842 & -0.1497 & -0.0991 & 1 & 0.0752 & 0.0267 & 0.0073 & 0.0899 & 0.0343 & -0.0267 \\
\hline p-value & 0.89968 & 0.81693 & 0.44720 & 0.38794 & 0.12362 & 0.30949 & 0 & 0.44069 & 0.78479 & 0.94063 & 0.35646 & 0.72548 & 0.78491 \\
\hline FORCUR & 0.1507 & 0.0499 & 0.1094 & 0.0124 & -0.0490 & 0.1035 & 0.0752 & 1 & -0.0967 & -0.1087 & -0.0941 & -0.0890 & -0.0460 \\
\hline p-value & 0.12115 & 0.60911 & 0.26135 & 0.89889 & 0.61550 & 0.28828 & 0.44069 & 0 & 0.32125 & 0.26469 & 0.33434 & 0.36161 & 0.63754 \\
\hline REV & 0.0667 & 0.0481 & 0.0926 & -0.1532 & 0.0327 & 0.0474 & 0.0267 & -0.0967 & 1 & 0.0514 & 0.0487 & 0.0941 & -0.1626 \\
\hline o-value & 0.49418 & 0.62197 & 0.34213 & 0.11519 & 0.73765 & 0.62759 & 0.78479 & 0.32125 & 0 & 0.59854 & 0.61814 & 0.33439 & 0.09424 \\
\hline
\end{tabular}




\begin{tabular}{lllllllllllllll}
\hline Variable & CHOICE & EQUITYCOMP JSECURITY & VOLATILITY LEVERAGE AFSSEC & \multicolumn{2}{l}{ PENSION FORCUR REV } & CASHFL & DISCQUAL LOGSIZE AUD \\
\hline CASHFL & $-0.1837^{* * *}$ & -0.0830 & $0.1913^{* *}$ & -0.0497 & 0.0788 & -0.1719 & 0.0073 & -0.1087 & 0.0514 & 1 & 0.1079 & -0.1126 & -0.0724 \\
p-value & 0.05835 & 0.39461 & 0.048578 & 0.61046 & 0.41908 & 0.07664 & 0.94063 & 0.26469 & 0.59854 & 0 & 0.26814 & 0.24789 & 0.45786 \\
DISCQUAL & -0.0259 & -0.1094 & $0.1999^{* *}$ & -0.0190 & 0.0385 & $-0.1734^{* * *}$ & 0.0899 & -0.0941 & 0.0487 & 0.1079 & 1 & $-0.5523^{*}$ & 0.0370 \\
p-value & 0.79078 & 0.26155 & 0.03909 & 0.84540 & 0.69349 & 0.07418 & 0.35646 & 0.33434 & 0.61814 & 0.26814 & 0 & $<0.0001$ & 0.70474 \\
LOGSIZE & 0.0309 & -0.0456 & -0.0366 & 0.0915 & 0.1248 & $0.2197 * *$ & 0.0343 & -0.0890 & 0.0941 & -0.1126 & $-0.5523^{*}$ & 1 & 0.1005 \\
p-value & 0.75175 & 0.64070 & 0.70757 & 0.34809 & 0.19999 & 0.02316 & 0.72548 & 0.36161 & 0.33439 & 0.24789 & $<0.0001$ & 0 & 0.30233 \\
AUD & -0.1226 & 0.2537 & 0.0538 & -0.0098 & -0.2476 & 0.1430 & -0.0267 & -0.0460 & $-0.1626^{* * *}$ & -0.0724 & 0.0370 & 0.1005 & 1 \\
p-value & 0.20805 & $0.00851^{*}$ & 0.58115 & 0.92009 & $0.01030^{* *}$ & 0.14145 & 0.78491 & 0.63754 & 0.09424 & 0.45786 & 0.70474 & 0.30233 & 0 \\
\hline
\end{tabular}

Notes: * significant at 1 percent level; ** significant at 5 percent level; *** significant at 10 percent level; **** Spearman correlation.

\subsubsection{Regression Results}

The results of the regression are shown in Table 6. Panel A presents the mean and standard deviation separately for both reporting methods. The last column reports on the results of a two-tailed t-test between the two samples. The results are not significant and lead to a rejection of the first four hypotheses. The p-values for VOLATILITY, JSECURITY, EQUITYCOMP and LEVERAGE are, all four, not significant, thus hypotheses 1a, 1b, 1c and 1d are rejected, respectively. However, there is a significant correlation between AFSSEC and CHOICE and CASHFL and CHOICE. As explained before, this is probably because cherry-picking firms (managing earnings through realized gains and losses on securities) have a tendency to report in the less separate statement method. The relationship between gains/losses from cash flow hedges (CASHFL) and the reporting choice (CHOICE) is negative, which means that firms with lower gains/losses from cash flow hedges tend to report in separate statements, although this relationship is significant at 10 percent. Panel B shows the coefficients and the p-values resulting from a probit regression for the first regression. In line with the two-tailed t-test, no significant relationship has been found between the key variables and reporting choice, thus hypotheses 1a, 1b, 1c and 1d are rejected. Again, there is a significant relationship between AFSSEC and CHOICE, although it is significant at a 10 percent level. In short, the regression results lead to a rejection of hypotheses $1 \mathrm{a}, 1 \mathrm{~b}, 1 \mathrm{c}$ and $1 \mathrm{~d}$.

Table 6. Regression 1 results $(n=107)$

\begin{tabular}{|c|c|c|c|c|c|}
\hline \multicolumn{6}{|c|}{ Panel A: T-test results } \\
\hline \multirow[b]{2}{*}{ Variable } & \multicolumn{2}{|c|}{ Single statement } & \multicolumn{2}{|c|}{ Separate statements } & \multirow{2}{*}{$\begin{array}{l}\text { Two-tailed t-test } \\
\text { P-value }\end{array}$} \\
\hline & Mean & St. Deviation & Mean & St. Deviation & \\
\hline EQUITYCOMP & 0.2424 & 0.1979 & 0.2653 & 0.2028 & 0.72255 \\
\hline JSECURITY & 0.8182 & 1.6030 & 0.6563 & 0.6622 & 0.44034 \\
\hline VOLATILITY & 3.3305 & 3.5788 & 3.0574 & 3.2130 & 0.79235 \\
\hline LEVERAGE & 0.2364 & 0.1080 & 0.2800 & 0.1321 & 0.29465 \\
\hline AFSSEC & 0.0909 & 0.3015 & 0.4167 & 0.4956 & $0.00174 *$ \\
\hline PENSION & 0.1818 & 0.4045 & 0.1979 & 0.4005 & 0.89985 \\
\hline FORCUR & 0.2727 & 0.4671 & 0.5208 & 0.5022 & 0.12127 \\
\hline REV & 0.0000 & 0.0000 & 0.0417 & 0.2009 & $\mathrm{NA}^{* * * *}$ \\
\hline CASHFL & 0.6364 & 0.5045 & 0.3438 & 0.4775 & $0.05825 * * *$ \\
\hline DISCQUAL & -0.2435 & 0.7624 & -0.3013 & 0.7286 & 0.80455 \\
\hline LOGSIZE & 7.1789 & 0.7944 & 7.2016 & 7.5815 & 0.90646 \\
\hline AUD & 0.8182 & 0.4045 & 0.6250 & 0.4867 & 0.20839 \\
\hline \multicolumn{6}{|c|}{ Panel B: Probit regression results } \\
\hline Variable & \multicolumn{2}{|c|}{ Coefficient } & \multicolumn{2}{|c|}{ St. Error } & $\mathrm{P}$-value \\
\hline EQUITYCOMP & \multicolumn{2}{|c|}{-0.0044} & \multicolumn{2}{|c|}{0.2355} & 0.85059 \\
\hline JSECURITY & \multicolumn{2}{|c|}{-0.1645} & \multicolumn{2}{|c|}{0.2266} & 0.46769 \\
\hline VOLATILITY & \multicolumn{2}{|c|}{-0.2644} & \multicolumn{2}{|c|}{0.2173} & 0.22373 \\
\hline LEVERAGE & \multicolumn{2}{|c|}{0.1705} & \multicolumn{2}{|c|}{0.2397} & 0.47695 \\
\hline AFSSEC & \multicolumn{2}{|c|}{0.6149} & \multicolumn{2}{|c|}{0.3311} & $0.06327 * * *$ \\
\hline PENSION & \multicolumn{2}{|c|}{0.9024} & \multicolumn{2}{|c|}{0.2266} & 0.68349 \\
\hline FORCUR & \multicolumn{2}{|c|}{0.3225} & \multicolumn{2}{|c|}{0.2278} & 0.15691 \\
\hline REV & \multicolumn{2}{|c|}{1.5687} & \multicolumn{2}{|c|}{198.3744} & 0.99369 \\
\hline CASHFL & \multicolumn{2}{|c|}{-0.3248} & \multicolumn{2}{|c|}{0.2082} & 0.11880 \\
\hline DISCQUAL & \multicolumn{2}{|c|}{0.1991} & \multicolumn{2}{|c|}{0.3086} & 0.51871 \\
\hline LOGSIZE & \multicolumn{2}{|c|}{0.0715} & \multicolumn{2}{|c|}{0.2564} & 0.78023 \\
\hline AUD & \multicolumn{2}{|c|}{-0.3031} & \multicolumn{2}{|c|}{0.2735} & 0.26780 \\
\hline
\end{tabular}

Notes: * significant at 1 percent level; ** significant at 5 percent level; *** significant at 10 percent level; ****=not available because single statement values were all constant $(0)$. 


\subsection{Second Regression}

\subsubsection{Descriptive Statistics}

Table 7 displays the descriptive statistics for the second regression. The mean of RETURN is 0.54 , which indicates that the average return of the 246 firms is $54 \%$. The average price-to-book ratio is 89 , the average price-to-earnings ratio is 26 and the average price-to-sales ratio is 0.00005 . The mean of total comprehensive income scaled by total assets is 0.070 and the mean of net income scaled by total assets is 0.068 , which indicates that total comprehensive income was slightly higher than net income. The mean of VOLATILITY for this sample is 2.4863 and slightly lower than the volatility of the sample used in the first regression (3.0855).

Table 7. Descriptive statistics for regression $2(n=246)$

\begin{tabular}{|c|c|c|c|c|c|}
\hline \multicolumn{6}{|c|}{ Panel A: Sample composition } \\
\hline \multicolumn{2}{|l|}{ Method } & \multicolumn{2}{|c|}{ Number of observations } & \multicolumn{2}{|c|}{ Percentage } \\
\hline \multicolumn{2}{|c|}{ Single statement reporting } & \multicolumn{2}{|l|}{12} & \multicolumn{2}{|l|}{$4.88 \%$} \\
\hline \multicolumn{2}{|c|}{ Separate statements reporting } & \multicolumn{2}{|l|}{234} & \multicolumn{2}{|l|}{$95.12 \%$} \\
\hline \multicolumn{6}{|c|}{ Panel B: Summary statistics } \\
\hline Variable & $1^{\text {st }}$ Quartile & Median & $3^{\text {rd }}$ Quartile & Mean & Standard Deviation \\
\hline RETURN & 0.2612 & 0.4719 & 0.7137 & 0.5403 & 0.3435 \\
\hline PBOOK & 1.5099 & 2.6271 & 141.1928 & 89.3507 & 154.7864 \\
\hline PEARN & 11.3882 & 16.1699 & 25.9586 & 26.0761 & 31.9090 \\
\hline PSALES & 0.000001303 & 0.0004361 & 0.000041927 & 0.000052905 & 0.000097591 \\
\hline CHOICE & 1 & 1 & 1 & 0.9512 & 0.2158 \\
\hline $\mathrm{CI}$ & 0.0343 & 0.0611 & 0.0947 & 0.0705 & 0.0500 \\
\hline NI & 0.0346 & 0.0557 & 0.0850 & 0.0682 & 0.0510 \\
\hline OCI & -0.0067 & 0.0052 & 0.0190 & 0.0043 & 0.0204 \\
\hline VOLATILITY & 0.9714 & 1.5406 & 2.5524 & 2.4863 & 2.4754 \\
\hline LEVERAGE & 0.2166 & 0.3128 & 0.4149 & 0.3185 & 0.1516 \\
\hline AFSSEC & 0 & 0 & 1 & 0.3780 & 0.4859 \\
\hline PENSION & 0 & 0 & 0 & 0.1789 & 0.3840 \\
\hline FORCUR & 0 & 0.5 & 1 & 0.5000 & 0.5010 \\
\hline REV & 0 & 0 & 0 & 0.0285 & 0.1666 \\
\hline CASHFL & 0 & 0 & 1 & 0.3902 & 0.4888 \\
\hline DISCQUAL & -0.6202 & -0.0685 & 0.3712 & -0.0581 & 0.9044 \\
\hline LOGSIZE & 6.4073 & 7.0299 & 7.4813 & 7.1160 & 0.5528 \\
\hline AUD & 0 & 1 & 1 & 0.6138 & 0.4879 \\
\hline
\end{tabular}

Table 8 presents the results of a Spearman correlation for the second regression. First of all, there are significant positive correlations between the investor reaction measures (for example, PEARN and RETURN, PSALES and PBOOK), because a higher/lower stock price influences all measurements in the same directions, so a positive significant correlation can be expected. Secondly, between NI/OCI and the different investor reaction measures there are significant positive correlations. This could also be expected, because as Kanagaretnam et al. (2009) and Goncharov and Hodgson (2011) concluded, these numbers are value relevant for investors and this should be incorporated in the stock price/investor reaction. Also, LOGSIZE and DISCQUAL are significantly correlated with some of the investor reactions both positively and negatively. This is unexpected, because a positive correlation would seem more logical. DISCQUAL could be positively related with investor reactions, because a better disclosure quality should give a positive impulse to stock prices as investors would prefer a higher disclosure quality. Moreover, a positive correlation between LOGSIZE and investor reaction measures could be expected as bigger companies have higher returns in general. 
Table 8. Correlation of variables in regression $2 * * * *$

\begin{tabular}{|c|c|c|c|c|c|c|c|c|}
\hline Variable & RETURN & PBOOK & PEARN & PSALES & CHOICE & $\mathrm{CI}$ & $\mathrm{NI}$ & OCI \\
\hline RETURN & 1 & -0.0557 & $0.2177^{*}$ & 0.0668 & -0.0625 & $0.1150 * * *$ & 0.0974 & 0.0293 \\
\hline $\mathrm{p}$-value & 0 & 0.38409 & 0.00060 & 0.29680 & 0.32903 & 0.07187 & 0.12764 & 0.64743 \\
\hline PBOOK & -0.0557 & 1 & $0.1088^{* * *}$ & $0.7122 *$ & -0.0757 & $0.2888^{*}$ & $0.4114 *$ & $-0.1300^{* *}$ \\
\hline $\mathrm{p}$-value & 0.38409 & 0 & 0.08871 & $<0.0001$ & 0.23635 & $<0.0001$ & $<0.0001$ & 0.04162 \\
\hline PEARN & $0.2177 *$ & $0.1088^{* * *}$ & 1 & $0.1110^{* *}$ & -0.0523 & $0.1654^{*}$ & $0.1208^{* * *}$ & $0.1066^{* * *}$ \\
\hline $\mathrm{p}$-value & 0.00060 & 0.08871 & 0 & 0.08228 & 0.41420 & 0.00944 & 0.05844 & 0.09517 \\
\hline PSALES & 0.0668 & $0.7122 *$ & $0.1110^{* * *}$ & 1 & -0.0181 & $0.2194 *$ & $0.3017 *$ & -0.0255 \\
\hline $\mathrm{p}$-value & 0.29680 & $<0.0001$ & 0.08228 & 0 & 0.77776 & 0.00054 & $<0.0001$ & 0.69062 \\
\hline CHOICE & -0.0625 & -0.0757 & -0.0523 & -0.0181 & 1 & -0.0074 & -0.0869 & 0.0635 \\
\hline p-value & 0.32903 & 0.23635 & 0.41420 & 0.77776 & 0 & 0.90749 & 0.17410 & 0.32085 \\
\hline $\mathrm{CI}$ & $0.1150 * * *$ & $0.2888^{*}$ & $0.1654 *$ & $0.2194 *$ & -0.0074 & 1 & $0.8329 *$ & $0.3903 *$ \\
\hline $\mathrm{p}$-value & 0.07187 & $<0.0001$ & 0.00944 & 0.00054 & 0.90749 & 0 & $<0.0001$ & $<0.0001$ \\
\hline NI & 0.0974 & $0.4114 *$ & $0.1208^{* * *}$ & $0.3017^{*}$ & -0.0869 & $0.8329 *$ & 1 & -0.0697 \\
\hline $\mathrm{p}$-value & 0.12764 & $<0.0001$ & 0.05844 & $<0.0001$ & 0.17410 & $<0.0001$ & 0 & 0.27624 \\
\hline OCI & 0.0293 & $-0.1300 * *$ & $0.1066^{* * *}$ & -0.0255 & 0.0635 & $0.3903 *$ & -0.0697 & 1 \\
\hline p-value & 0.64743 & 0.04162 & 0.09517 & 0.69062 & 0.32085 & $<0.0001$ & 0.27624 & 0 \\
\hline VOLATILITY & -0.0384 & 0.0350 & 0.0838 & 0.0726 & -0.0159 & 0.0715 & 0.0452 & $0.1353 *$ \\
\hline $\mathrm{p}$-value & 0.54844 & 0.58430 & 0.19007 & 0.25669 & 0.80334 & 0.26363 & 0.47990 & 0.03398 \\
\hline LEVERAGE & $-0.1746^{*}$ & -0.0147 & $-0.2284^{*}$ & -0.0267 & $0.1196^{* * *}$ & -0.1624 & $-0.1307 * *$ & -0.0268 \\
\hline $\mathrm{p}$-value & 0.00610 & 0.81882 & 0.00031 & 0.67672 & 0.06110 & 0.01080 & 0.04064 & 0.67597 \\
\hline AFSSEC & $0.1101 * * *$ & $-0.1348 * *$ & 0.0214 & -0.0953 & 0.0987 & -0.0434 & -0.0705 & 0.0329 \\
\hline p-value & 0.08484 & 0.03469 & 0.73770 & 0.13585 & 0.12248 & 0.49789 & 0.27016 & 0.60754 \\
\hline PENSION & 0.0125 & $0.1751^{*}$ & 0.0510 & $0.2003 *$ & 0.0072 & $0.1295^{* *}$ & 0.0871 & $0.1274 * *$ \\
\hline $\mathrm{p}$-value & 0.84464 & 0.00595 & 0.42578 & 0.00162 & 0.91040 & 0.04245 & 0.17319 & 0.04592 \\
\hline FORCUR & $0.1095^{* * *}$ & $-0.1900^{*}$ & $0.1225 * * *$ & -0.0644 & $0.1132 * * *$ & $0.1989^{*}$ & -0.0588 & $0.5904 *$ \\
\hline $\mathrm{p}$-value & 0.08649 & 0.00281 & 0.05508 & 0.31413 & 0.07631 & 0.00174 & 0.35821 & $<0.0001$ \\
\hline REV & -0.0453 & -0.0343 & -0.0029 & -0.0883 & 0.0388 & -0.0188 & 0.0046 & -0.0122 \\
\hline p-value & 0.47935 & 0.59256 & 0.96353 & 0.16720 & 0.54493 & 0.76947 & 0.94213 & 0.84862 \\
\hline CASHFL & -0.0863 & -0.1549 & -0.0993 & $-0.1336^{*}$ & -0.0896 & -0.0474 & -0.0472 & 0.0613 \\
\hline p-value & 0.17734 & 0.01508 & 0.12029 & 0.03636 & 0.16094 & 0.45884 & 0.46107 & 0.33837 \\
\hline DISCQUAL & -0.0909 & 0.0179 & $-0.2027^{*}$ & $0.1461 * *$ & 0.0433 & $-0.1573 * *$ & $-0.1689^{*}$ & 0.0723 \\
\hline p-value & 0.15498 & 0.77953 & 0.00142 & 0.02201 & 0.49856 & 0.01356 & 0.00799 & 0.25840 \\
\hline LOGSIZE & 0.0079 & $-0.2332 *$ & $0.1901 *$ & $-0.4528^{*}$ & -0.0234 & $0.1298 * *$ & $0.1617 * *$ & $-0.1210^{* * *}$ \\
\hline $\mathrm{p}$-value & 0.90187 & $0.00023^{*}$ & 0.00279 & $<0.0001$ & 0.71495 & 0.04199 & 0.01114 & 0.05806 \\
\hline AUD & -0.0272 & 0.0292 & 0.0293 & 0.0145 & -0.0633 & -0.0686 & -0.0324 & -0.1011 \\
\hline $\mathrm{p}$-value & 0.67072 & 0.64811 & 0.64723 & 0.82059 & 0.32224 & 0.28353 & 0.61286 & 0.11379 \\
\hline
\end{tabular}

Notes: * significant at 1 percent level; ** significant at 5 percent level; *** significant at 10 percent level; **** Spearman correlation.

\subsubsection{Regression Results}

The results of the second regression are shown in Table 9. For all the investor reaction measures, both the results of the two-tailed t-test (Panel A) and results of the linear regressions (consecutive panels) are reported on Table 9. The results of the two-tailed t-tests indicate that only stock returns (PEARN) are significantly different for the two reporting method samples. For the other three measures (PSALES, PBOOK, RETURN), the p-value of the two-tailed t-test is not significant. The results of the linear regression show that for two investor reaction measures the association with CHOICE is significant (RETURN with p-value 0.09333 and PEARN with p-value 0.01513). However, the coefficient that reports on the relationship between investor reaction and reporting choice is negative for both measures, which indicates that firms that report in a single statement have a higher stock return, while the hypothesis states that firms that report in a less salient separate statement should have higher stock returns. For the other two measures the results are not significant (PBOOK with p-value 0.66330 and PSALES with p-value 0.35742). In short, the results are mixed with a big part being not significant and the two significant results being the opposite direction of the hypothesis. 
Table 9. Regression 2 results $(n=246)$

\begin{tabular}{|c|c|c|c|c|c|}
\hline \multicolumn{6}{|c|}{ Panel A: T-test results } \\
\hline \multirow[b]{2}{*}{ Variable } & \multicolumn{2}{|c|}{ Single statement } & \multicolumn{2}{|c|}{ Separate statement } & \multirow{2}{*}{$\begin{array}{l}\text { Two-tailed t-test } \\
\text { P-value }\end{array}$} \\
\hline & Mean & St. Deviation & Mean & St. Deviation & \\
\hline RETURN & 0.6700 & 0.4232 & 0.5337 & 0.3387 & 0.18060 \\
\hline PBOOK & 87.6461 & 133.1172 & 89.4381 & 156.0642 & 0.96889 \\
\hline PEARN & 47.1065 & 51.7941 & 24.9976 & 30.3320 & $0.01893 * *$ \\
\hline PSALES & 0.0001 & 0.0001 & 0.0001 & 0.0001 & 0.48893 \\
\hline $\mathrm{CI}$ & 0.0732 & 0.0493 & 0.0704 & 0.0502 & 0.65165 \\
\hline NI & 0.0805 & 0.0491 & 0.0675 & 0.0511 & 0.39101 \\
\hline OCI & -0.0003 & 0.0224 & 0.0045 & 0.0204 & 0.42524 \\
\hline VOLATILITY & 2.8689 & 2.9209 & 2.4667 & 2.4561 & 0.58402 \\
\hline LEVERAG & 0.2368 & 0.1015 & 0.3227 & 0.1527 & $0.055566^{* * *}$ \\
\hline AFSSEC & 0.1667 & 0.3892 & 0.3889 & 0.4885 & 0.12253 \\
\hline PENSION & 0.1667 & 0.3892 & 0.1795 & 0.3846 & 0.91047 \\
\hline FORCUR & 0.2500 & 0.4523 & 0.5128 & 0.5009 & $0.07630 * * *$ \\
\hline REV & 0.0000 & 0.0000 & 0.0299 & 0.1707 & NA**** \\
\hline CASHFL & 0.5833 & 0.5149 & 0.3803 & 0.4865 & 0.16104 \\
\hline DISCQUAL & -0.1695 & 0.9770 & -0.0524 & 0.9024 & 0.66258 \\
\hline LOGSIZE & 7.2253 & 0.7743 & 7.1104 & 0.5408 & 0.48358 \\
\hline AUD & 0.7500 & 0.4523 & 0.6068 & 0.64895 & 0.32248 \\
\hline \multicolumn{6}{|c|}{ Panel B: Linear regression results (dependant variable=RETURN) } \\
\hline Variable & \multicolumn{2}{|r|}{ Coefficient } & St. Error & \multicolumn{2}{|r|}{ P-value } \\
\hline CHOICE & \multicolumn{2}{|r|}{-0.1083} & 0.0643 & \multicolumn{2}{|r|}{$0.09333 * * *$} \\
\hline $\mathrm{CI}$ & \multicolumn{2}{|r|}{0.3217} & 0.2529 & \multicolumn{2}{|r|}{0.20461} \\
\hline NI & \multicolumn{2}{|r|}{-0.2535} & 0.2421 & \multicolumn{2}{|r|}{0.29596} \\
\hline OCI & \multicolumn{2}{|r|}{-0.1910} & 0.1344 & \multicolumn{2}{|r|}{0.15678} \\
\hline VOLATILITY & \multicolumn{2}{|r|}{-0.0790} & 0.0634 & & 0.21373 \\
\hline LEVERAGE & & -0.1722 & 0.0645 & & $0.00810^{*}$ \\
\hline AFSSEC & & 0.1384 & 0.0660 & & $0.03711^{* *}$ \\
\hline PENSION & & 0.0059 & 0.0640 & & 0.92649 \\
\hline FORCUR & & 0.1329 & 0.0764 & & $0.08344 * * *$ \\
\hline REV & & -0.0531 & 0.0638 & & 0.40653 \\
\hline CASHFL & & -0.0735 & 0.0649 & & 0.25872 \\
\hline DISCQUAL & & 0.0129 & 0.0730 & & 0.86009 \\
\hline LOGSIZE & & -0.0627 & 0.0742 & & 0.39871 \\
\hline AUD & & -0.0658 & 0.0645 & & 0.30900 \\
\hline Panel C: Linear & ssion resul & (dependant variable $=\mathrm{PB}$ & & & \\
\hline Variable & & Coefficient & St. Error & & P-value \\
\hline CHOICE & & -0.0255 & 0.0585 & & 0.66330 \\
\hline $\mathrm{CI}$ & & 0.2946 & 0.2301 & & 0.20172 \\
\hline NI & & -0.0649 & 0.2202 & & 0.76841 \\
\hline OCI & & -0.0733 & 0.1223 & & 0.54956 \\
\hline VOLATILITY & & -0.0176 & 0.0577 & & 0.76112 \\
\hline LEVERAGE & & 0.1680 & 0.0586 & & $0.00456^{*}$ \\
\hline AFSSEC & & -0.0003 & 0.0601 & & 0.99640 \\
\hline PENSION & & 0.1742 & 0.0582 & & $0.00309^{*}$ \\
\hline FORCUR & & -0.1233 & 0.0659 & & $0.07758^{* * *}$ \\
\hline REV & & 0.0327 & 0.0581 & & 0.57412 \\
\hline CASHFL & & -0.0977 & 0.0591 & & $0.09953 * * *$ \\
\hline DISCQUAL & & -0.2071 & 0.0664 & & $0.00206^{*}$ \\
\hline LOGSIZE & & -0.4314 & 0.0675 & & $<0.0001^{*}$ \\
\hline AUD & & 0.0049 & 0.0587 & & 0.93373 \\
\hline Panel D: Linear & ssion resul & (dependant variable $=\mathrm{PE}$ & & & \\
\hline Variable & & Coefficient & St. Error & & P-value \\
\hline CHOICE & & -0.1565 & 0.0640 & & $0.01513^{* *}$ \\
\hline $\mathrm{CI}$ & & 0.1598 & 0.2516 & & 0.52589 \\
\hline NI & & -0.2202 & 0.2408 & & 0.36155 \\
\hline OCI & & 0.0823 & 0.1337 & & 0.53902 \\
\hline VOLATILITY & & -0.0321 & 0.0631 & & 0.61176 \\
\hline
\end{tabular}




\begin{tabular}{llll}
\hline LEVERAGE & -0.0840 & 0.0641 & 0.19141 \\
AFSSEC & 0.0714 & 0.0657 & 0.27792 \\
PENSION & 0.670 & 0.0637 & 0.29396 \\
FORCUR & -0.766 & 0.0760 & 0.31479 \\
REV & -0.0208 & 0.0635 & 0.74363 \\
CASHFL & -0.0739 & 0.0646 & 0.25387 \\
DISCQUAL & -0.1687 & 0.0726 & 0.02107 \\
LOGSIZE & 0.0526 & 0.0738 & $0 . .47715$ \\
AUD & -0.0655 & 0.0642 & 0.30835 \\
\hline Panel E: Linear regression results (dependant variable=PSALES) & & \\
\hline Variable & Coefficient & St. Error & P-value \\
\hline CHOICE & -0.0540 & 0.0586 & 0.35742 \\
CI & 0.1052 & 0.2304 & 0.64847 \\
NI & 0.1214 & 0.2206 & 0.58249 \\
OCI & -0.1041 & 0.1225 & 0.39611 \\
VOLATILITY & 0.0517 & 0.0578 & 0.37121 \\
LEVERAGE & 0.0394 & 0.0587 & 0.50328 \\
AFSSEC & -0.0200 & 0.0602 & 0.73965 \\
PENSION & 0.1311 & 0.0583 & $0.02552^{* *}$ \\
FORCUR & -0.0280 & 0.0696 & 0.68838 \\
REV & 0.0416 & 0.0582 & 0.47499 \\
CASHFL & -0.0359 & 0.0592 & 0.54424 \\
DISCQUAL & -0.0911 & 0.0665 & $0.00446^{*}$ \\
LOGSIZE & -0.4924 & 0.0676 & $<0.0001^{*}$ \\
AUD & -0.0403 & 0.0588 & 0.49379 \\
\hline
\end{tabular}

Notes: * significant at 1 percent level; ** significant at 5 percent level; *** significant at 10 percent level; **** not available because single statement values were all constant $(0)$.

\subsection{Robustness Test}

\subsubsection{Descriptive Statistics}

Table 10 shows the descriptive statistics for the third regression. In Panel A, the composition of the sample is presented. There are 165 firms, of which 154 (93.33\%) are using the separate statement method, only 11 firms (6.67\%) report their comprehensive income in one single statement. In Panel B, the summary descriptive statistics are reported. The mean of TOTALCOMP is 0.0003 , which indicates that on average the total compensation of the CEO scaled by total assets is $0.03 \%$. The mean of JSECURITY is 0.6788 , slightly higher than the JSECURITY in the first regression (0.6729). VOLATILITY equals 2.7837 and is lower than the volatility in the first regression (3.0855).

Table 10. Descriptive statistics for regression $3(\mathrm{n}=165)$

\begin{tabular}{|c|c|c|c|c|c|}
\hline \multicolumn{6}{|c|}{ Panel A: Sample composition } \\
\hline \multicolumn{2}{|l|}{ Method } & \multicolumn{2}{|c|}{ Number of observations } & \multicolumn{2}{|c|}{ Percentage } \\
\hline \multicolumn{2}{|c|}{ Single statement reporting } & \multicolumn{2}{|l|}{11} & \multicolumn{2}{|c|}{$6.67 \%$} \\
\hline \multicolumn{2}{|c|}{ Separate statements reporting } & 154 & & \multicolumn{2}{|c|}{$93.33 \%$} \\
\hline \multicolumn{6}{|c|}{ Panel B: Summary statistics } \\
\hline Variable & $1^{\text {st }}$ Quartile & Median & $3^{\text {rd }}$ Quartile & Mean & Standard Deviation \\
\hline CHOICE & 1 & 1 & 1 & 0.9333 & 0.2502 \\
\hline TOTALCOMP & 0.000069 & 0.000185 & 0.000490 & 0.0003 & 0.0003 \\
\hline JSECURITY & 0 & 1 & 1 & 0.6788 & 0.6438 \\
\hline VOLATILITY & 0.9818 & 1.6317 & 2.9320 & 2.7837 & 2.9484 \\
\hline LEVERAGE & 0.1894 & 0.2983 & 0.4151 & 0.3100 & 0.1511 \\
\hline AFSSEC & 0 & 0 & 1 & 0.3758 & 0.4858 \\
\hline PENSION & 0 & 0 & 0 & 0.2242 & 0.4184 \\
\hline FORCUR & 0 & 0 & 1 & 0.4970 & 0.5015 \\
\hline REV & 0 & 0 & 0 & 0.0303 & 0.1719 \\
\hline CASHFL & 0 & 0 & 1 & 0.3758 & 0.4858 \\
\hline DISCQUAL & -0.5901 & -0.0515 & 0.3217 & -0.1336 & 0.7769 \\
\hline LOGSIZE & 6.6221 & 7.0025 & 7.5252 & 7.0923 & 0.5957 \\
\hline AUD & 0 & 1 & 1 & 0.6121 & 0.4888 \\
\hline
\end{tabular}


Table 11 presents the results of a Spearman correlation test between the variables in the third regression and the corresponding p-values. The table shows the same characteristics as the results of the Spearman correlation in the first regression. There is again a positive relationship between AFSSEC and VOLATILITY, which means that firms with a relative more volatile comprehensive income have higher gains/losses from available-for-sale securities. Consistent with the results of the Spearman correlation in the first regression, the correlation between LOGSIZE and AFSSEC is also significant and positive. This could be, because bigger firms should have more resources to invest in available-for-sale securities and could also have a higher expertise to make gains on these securities.

Table 11. Correlation of variables in regression $3 * * * *$

\begin{tabular}{|c|c|c|c|c|c|c|c|c|c|c|c|c|c|}
\hline Variable & CHOICE & TOTALCOMP & JSECURITY & VOLATILITY & LEVERAGE & AFSSEC & PENSION & FORCUR & REV & CASHFL & DISCQUAL & LOGSIZE & AUD \\
\hline CHOICE & 1 & -0.1128 & -0.0657 & -0.0403 & 0.1199 & 0.1572 & 0.0272 & 0.1199 & 0.0472 & $-0.1438 * * *$ & 0.0301 & -0.0168 & -0.1130 \\
\hline p-value & 0 & 0.14920 & 0.40166 & 0.60690 & 0.12497 & 0.04385 & 0.72861 & 0.12506 & 0.54638 & 0.06540 & 0.70083 & 0.82991 & 0.14822 \\
\hline TOTALCOMP & -0.1128 & 1 & -0.0548 & -0.0369 & $-0.1589^{* *}$ & $-0.1874 * *$ & $0.1626^{* *}$ & -0.0176 & -0.1262 & -0.0200 & $0.2869^{*}$ & $-0.6253^{*}$ & 0.0880 \\
\hline p-value & 0.14920 & 0 & 0.48381 & 0.63725 & 0.04163 & 0.01608 & 0.03698 & 0.82266 & 0.10620 & 0.79883 & 0.00020 & $<0.0001$ & 0.26064 \\
\hline JSECURITY & -0.0657 & -0.0548 & 1 & 0.0529 & $-0.1475^{* * *}$ & -0.0592 & 0.0349 & 0.0339 & 0.0873 & 0.0851 & 0.0867 & 0.0210 & -0.0122 \\
\hline $\mathrm{p}$-value & 0.40166 & 0.48381 & 0 & 0.49961 & 0.05874 & 0.44977 & 0.65624 & 0.66532 & 0.26446 & 0.27662 & 0.26775 & 0.78917 & 0.87658 \\
\hline VOLATILITY & -0.0403 & -0.0369 & 0.0529 & 1 & 0.1006 & $0.1845^{* *}$ & 0.0580 & $0.1670^{* *}$ & -0.0676 & 0.0594 & -0.0144 & 0.0757 & -0.0212 \\
\hline $\mathrm{p}$-value & 0.60690 & 0.63725 & 0.49961 & 0 & 0.19814 & 0.01781 & 0.45911 & 0.03217 & 0.38820 & 0.44823 & 0.85419 & 0.33322 & 0.78717 \\
\hline LEVERAGE & 0.1199 & $-0.1589 * *$ & $-0.1475^{* * *}$ & 0.1006 & 1 & $0.1590^{* *}$ & -0.0500 & -0.0664 & 0.0572 & 0.0389 & 0.1179 & -0.0340 & $-0.1802 * *$ \\
\hline p-value & 0.12497 & 0.04163 & 0.05874 & 0.19814 & 0 & 0.04149 & 0.52290 & 0.39617 & 0.46541 & 0.61959 & 0.13149 & 0.66469 & 0.02066 \\
\hline AFSSEC & $0.1572^{* *}$ & $-0.1874 * *$ & -0.0592 & $0.1845^{* *}$ & $0.1590^{* *}$ & 1 & -0.0871 & 0.0047 & 0.0818 & -0.0852 & $-0.1591^{* *}$ & $0.1986^{* *}$ & $0.1297^{* * *}$ \\
\hline p-value & 0.04385 & 0.01608 & 0.44977 & 0.01781 & 0.04149 & 0 & 0.26566 & 0.95215 & 0.29563 & 0.27633 & 0.04132 & 0.01065 & 0.09694 \\
\hline PENSION & 0.0272 & $0.1626^{* *}$ & 0.0349 & 0.0580 & -0.0500 & -0.0871 & 1 & 0.1050 & -0.0103 & 0.0029 & 0.1205 & $-0.1611^{* *}$ & -0.0193 \\
\hline p-value & 0.72861 & 0.03698 & 0.65624 & 0.45911 & 0.52290 & 0.26566 & 0 & 0.17944 & 0.89569 & 0.97038 & 0.12299 & 0.03884 & 0.80507 \\
\hline FORCUR & 0.1199 & -0.0176 & 0.0339 & $0.1670^{* *}$ & -0.0664 & 0.0047 & 0.1050 & 1 & -0.0343 & 0.0047 & 0.0050 & -0.0776 & -0.0546 \\
\hline p-value & 0.12506 & 0.82266 & 0.66532 & 0.03217 & 0.39617 & 0.95215 & 0.17944 & 0 & 0.66167 & 0.95215 & 0.94950 & 0.32136 & 0.48588 \\
\hline REV & 0.0472 & -0.1262 & 0.0873 & -0.0676 & 0.0572 & 0.0818 & -0.0103 & -0.0343 & 1 & 0.0818 & 0.0234 & 0.1217 & -0.0770 \\
\hline p-value & 0.54638 & 0.10620 & 0.26446 & 0.38820 & 0.46541 & 0.29563 & 0.89569 & 0.66167 & 0 & 0.29563 & 0.76534 & 0.11925 & 0.32552 \\
\hline CASHFL & $-0.1438^{* *}$ & -0.0200 & 0.0851 & 0.0594 & 0.0389 & -0.0852 & 0.0029 & 0.0047 & 0.0818 & 1 & $0.1397 * *$ & -0.0602 & -0.1015 \\
\hline p-value & 0.06540 & 0.79883 & 0.27662 & 0.44823 & 0.61959 & 0.27633 & 0.97038 & 0.95215 & 0.29563 & 0 & 0.07362 & 0.44231 & 0.19443 \\
\hline DISCQUAL & 0.0301 & $0.2869^{*}$ & 0.0867 & -0.0144 & 0.1179 & $-0.1591 * *$ & 0.1205 & 0.0050 & 0.0234 & $0.1397 * * *$ & 1 & $-0.5361^{*}$ & -0.0069 \\
\hline $\mathrm{p}$-value & 0.70083 & 0.00020 & 0.26775 & 0.85419 & 0.13149 & 0.04132 & 0.12299 & 0.94950 & 0.76534 & 0.07362 & 0 & $<0.0001$ & 0.92963 \\
\hline LOGSIZE & -0.0168 & $-0.6253^{*}$ & 0.0210 & 0.0757 & -0.0340 & $0.1986^{* *}$ & $-0.1611^{* *}$ & -0.0776 & 0.1217 & -0.0602 & $-0.5361^{*}$ & 1 & 0.0718 \\
\hline p-value & 0.82991 & $<0.0001$ & 0.78917 & 0.33322 & 0.66469 & 0.01065 & 0.03884 & 0.32136 & 0.11925 & 0.44231 & $<0.0001$ & 0 & 0.35897 \\
\hline AUD & -0.1130 & 0.0880 & -0.0122 & -0.0212 & $-0.1802 * *$ & $0.1297 * * *$ & -0.0193 & -0.0546 & -0.0770 & -0.1015 & -0.0069 & 0.0718 & 1 \\
\hline $\mathrm{p}$-value & 0.14822 & 0.26064 & 0.87658 & 0.78717 & 0.02066 & 0.09694 & 0.80507 & 0.48588 & 0.32552 & 0.19443 & 0.92963 & 0.35897 & 0 \\
\hline
\end{tabular}

Notes: * significant at 1 percent level; $* *$ significant at 5 percent level; $* * *$ significant at 10 percent level; **** Spearman correlation.

\subsubsection{Regression Results}

The results of the third regression are shown in Table 12. Panel A presents the results of a two-tailed t-test. Contradictive to the results of the first regression, the variable TOTALCOMP is significantly different for the single statement and separate statement samples. The t-test has a p-value of 0.08719 and is significant at a 10 percent level. Besides TOTALCOMP, LEVERAGE (p-value 0.09703), AFSSEC (p-value 0.04377) and CASHFL (0.06535) are also significantly different for the two samples. Panel B shows the results of a linear regression of the model. TOTALCOMP is again significant at a 10 percent level with a p-value of 0.07691 . However, as the hypothesis would predict a positive coefficient, the results show a negative coefficient, indicating CEOs of firms that have a higher total compensation choose to report the firm's comprehensive income in a single statement. Moreover, VOLATILITY is significantly associated with CHOICE with a p-value of 0.07192. Again, while a positive coefficient is expected, the results show a negative coefficient, indicating that firms that have a higher volatility of other comprehensive income report on a single statement of comprehensive income, while the opposite is expected. For the other two key variables (LEVERAGE and JSECURITY) no significant result has been found. In short, the results are mixed and do not support the hypothesis. TOTALCOMP (hypothesis 1c) and VOLATILITY (hypothesis 1a) show significant p-values, but in the opposite direction. The other two values are not significant, thus hypothesis $1 \mathrm{~b}$ and $1 \mathrm{~d}$ are rejected. 
Table 12. Regression 3 results $(\mathrm{n}=165)$

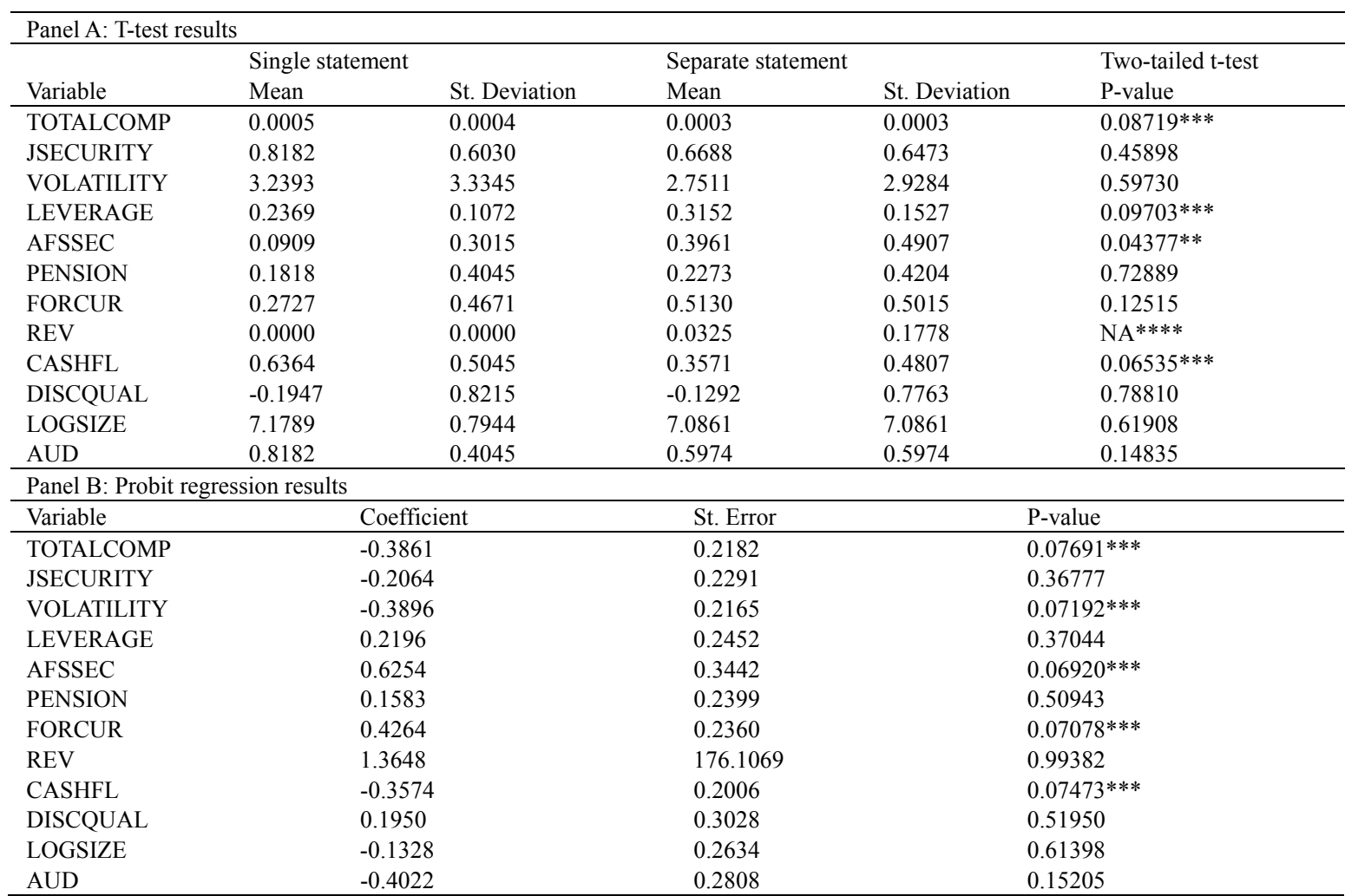

Notes: * significant at 1 percent level; ** significant at 5 percent level; *** significant at 10 percent level; **** not available because single statement values were all constant $(0)$.

\section{Discussion and Conclusions}

After 1 January 2009 firms implementing IFRS have the option to report their comprehensive income in two ways: in a single statement that consists of a statement of comprehensive income or in two separate statements split up in an income statement and a comprehensive income statement (IASB, 2007). This research has investigated whether the reporting way of comprehensive income is influenced by some factors and whether the investors do value the choice by looking at stock returns (measured in different ways).

It has been argued that other comprehensive income is more volatile than net income. As investors focus on bottom line numbers, income in single statement reports is regarded to be more volatile than separate statement reports, although only the location changes and not the actual numbers. Since investors regard more volatile firms as more risky, it is expected that firms reporting in a single statement would expect a negative investor reaction. Besides the investor reaction to comprehensive reporting, the motivations for choosing a certain reporting method have also been investigated. Because firms that have higher equity-based incentives or lower job security have more to lose from a negative investor reaction (lower stock price), it has been hypothesized that firms with CEOs that have higher equity-based incentives or lower job security would report their comprehensive income in separate statements instead of a single statement. Moreover, it is expected that firms with a higher leverage and more volatile comprehensive income relative to net income will report their comprehensive income in separate statements instead of a single statement.

The research sample consisted of firms on the S\&P Europe 350 Index. The sample size for the first regression was 107 firms and for the second regression 246 firms. Two regression models have been used to test the hypotheses. In the first logit model, the reporting choice has been the dependant variable, while in the second linear model the investor reaction, measured in different ways was the dependant variable.

The results do not support our hypotheses. The first regression does not indicate a significant association between the reporting choice of firms and the volatility, job security, equity-based incentives and leverage of the firms. The results of the second regression provide some evidence that there is an association between the stock returns and the reporting choice. The price-earnings ratio and stock returns are associated with reporting choice, but in the opposite direction. Moreover, a robustness test has been conducted, which included the total 
compensation of the CEO instead of the equity-based compensation. The results suggest that there is a significant association between the total compensation of the CEO and the volatility on one side and the reporting choice of firms on the other side. However, these results are not significant in the expected direction, but in the opposite direction.

Another important result is that, in both the first regression and the robustness test, it has been found that there is a significant association between the realized gains or losses on available-for-sale securities and reporting choice of firms. The positive correlation indicates that firms with higher gains/losses from available-for-sale securities tend to report in the less salient separate statements method and this is in line with the results of Lee et al. (2006), who concluded that cherry-picking firms (managing earnings through realized gains and losses on securities) have a tendency to report in the less salient statement of equity instead of the more salient performance statement.

The contribution made by this research is twofold. First of all, the empirical contribution made is that this research replicates the two hypotheses of Bamber et al. (2010) for European firms implementing IFRS instead of US firms implementing US GAAP. The context differs from previous papers, because a European setting is used instead of an US setting (Bamber et al., 2010; Lee et al., 2006) and archival quantitative data is used instead of experiments (Hirst and Hopkins, 1998; Hunton et al., 2006; Maines and McDaniel, 2000). Moreover, there is little empirical contribution made until now regarding the determinants of manager's comprehensive income reporting location choices. Moreover, the prior literature compares performance reporting (reporting in an income-statement format) with reporting in a statement of equity. This research is different, because it compares the two options in the income-statement approach (single statement reporting and separate statements reporting) for the first time and this difference in salience could be smaller than the difference in salience between performance reporting and reporting in an equity statement.

Secondly, there is a social contribution made, because these results could be of importance to the standard setters, since there is currently a project going on at the IASB, which will eliminate the separate statements choice and only leave the option for IFRS adopting firms to report comprehensive income in a single statement.

\section{Study Limitations and Recommendations}

There are several limitations in this study. First of all, the sample size is very small. The sample size for the first regression is 107 firms, for the second regression 246 firms. Secondly, a big part of the firms in the sample (89.73\% in the first regression and $95.12 \%$ in the second regression) report their comprehensive income in separate statements, which makes it difficult to get statistical significant and reliable results. Thirdly, the equity-based incentives have been measured by looking at the reported numbers in the financial statements. Most of the firms do not report the equity-based incentives of the CEO separately and if they do, it is not always clear or comparable as corporate governance rules differ between countries.

Future research could be of qualitative kind, for example interviews with CEOs or investors about the reasons for choosing a specific reporting method or the preference and reaction of investors. Also, in future research the equity-based incentives of CEO's could be calculated separately for every firm in the same way to increase the reliability of the measure.

\section{References}

Ball, R., \& Brown, P. (1968). An Empirical Evaluation of Accounting Income Numbers. Journal of Accounting Research, 6(2), 159-178. http://dx.doi.org/10.2307/2490232

Bamber, L. S., Jiang, J., Petroni, K. R., \& Wang, I. Y. (2010). Comprehensive income: who's afraid of performance reporting? The Accounting Review, 85(1), 97-126. http://dx.doi.org/10.2139/ssrn.930699

Cahan, S. F., Courtenay, S. M., Gronewoller, P. L., \& Upton, D. R. (2000). Value relevance of mandated comprehensive income disclosure. Journal of Business Finance and Accounting, 27(9-10), 1273-1300. http://dx.doi.org/10.1111/1468-5957.00356

Chambers, D., Linsmeier, T., Shakespeare, C., \& Sougiannis, T. (2007). An evaluation of SFAS No. 130 comprehensive income disclosures. Review of Accounting Studies, 12(4), 557-593. http://dx.doi.org/10.1007/s11142-007-9043-2

Cheng, C. S. A., Cheung, J. K., \& Gopalakrishnan, V. (1993). On the usefulness of operating income, net income and comprehensive income in explaining security returns. Accounting and Business Research, 23(91), 195-203. http://dx.doi.org/10.1080/00014788.1993.9729879

Dechow, P. M. (1994). Accounting earnings and cash flows as measures of firm performance: The role of 
accounting accruals. Journal of Accounting and Economics, 3-42. http://dx.doi.org/10.1016/0165-4101(94)90016-7

Deloitte. (2007). IAS Plus: Revised standard on presentation of financial statements. Retrieved October 2007 from http://www.iasplus.com/iasplus/0709ias1 revised.pdf

Deloitte. (2010). IFRS in focus: IASB proposes changes to the presentation of profit or loss and other comprehensive income in IAS 1. Retrieved June 2010 from http://www.iasplus.com/iasplus/1006comprehensiveincome.pdf

Desai, H., Hogan, C., \& Wilkins, M. (2006). The reputational penalty for aggressive accounting: Earnings restatements and management turnover. The Accounting Review, 81(1), 83-112. http://dx.doi.org/10.2308/accr.2006.81.1.83

Dhaliwal, D., Subramanyam, K., \& Trezevant, R. (1999). Is comprehensive income superior to net income as a measure of firm performance? Journal of Accounting and Economics, 26, 43-67. http://dx.doi.org/10.1016/S0165-4101(98)00033-0

Farrelly, G., Ferris, K., \& Reichenstein, W. (1985). Perceived risk, market risk, and accounting determined risk measures. The Accounting Review, 60(2), 278-288.

Financial Accounting Standards Board (FASB). (1996). Exposure Draft: Reporting Comprehensive Income. Norwalk, CT: FASB.

Financial Accounting Standards Board (FASB). (1997). Reporting Comprehensive Income Statement of Financial Accounting Standards No.130. Norwalk, CT: FASB.

Goel, A., \& Thakor, A. (2003). Why do firms smooth earnings? The Journal of Business, 76(1), 151-192. http://dx.doi.org/10.1086/344117

Goncharov, I., \& Hodgson, A. (2011). Measuring and reporting income in Europe. Journal of International Accounting Research, 10(1), 27-59. http://dx.doi.org/10.2308/jiar.2011.10.1.27

Goyal, V., \& Park, C. (2002). Board leadership structure and CEO turnover. Journal of CorporateFinance, 8(1), 49-66. http://dx.doi.org/10.1016/S0929-1199(01)00028-1

Graham, J., Harvey, C., \& Rajgopal, S. (2005). The economic implications of corporate financial reporting. Journal of Accounting and Economics, 40(1-3), 3-73. http://dx.doi.org/10.1016/j.jacceco.2005.01.002

Henry, E. (2011). Presentation of comprehensive income: Another (small) step towards convergence. Journal of Corporate Accounting \& Finance, 23(1), 85-90. http://dx.doi.org/10.1002/jcaf.21726

Hirshleifer, D., \& Teoh, S. (2003). Limited attention, information disclosure, and financial reporting. Journal of Accounting and Economics, 36(1-3), 337-386. http://dx.doi.org/10.1016/j.jacceco.2003.10.002

Hirst, D., \& Hopkins, P. (1998). Comprehensive income reporting and analysts' valuation judgments. Journal of Accounting Research, 36, 47-74. http://dx.doi.org/10.2307/2491306

Hunton, J., Libby, R., \& Mazza, C. (2006). Financial reporting transparency and earnings management. The Accounting Review, 81(1), 135-157. http://dx.doi.org/10.2308/accr.2006.81.1.135

Huson, M., Parrino, R., \& Starks, L. (2001). Internal monitoring mechanisms and CEO turnover: Along-term perspective. The Journal of Finance, 56(6), 2265-2297. http://dx.doi.org/10.1111/0022-1082.00405

International Accounting Standards Board (IASB). (2007). International Accounting Standard 1: Presentation of financial statements. London, U.K.: IASB.

Kanagaretnam, K., Mathieu, R., \& Shehata, M. (2009). Usefulness of comprehensive income reporting in Canada. Journal of Accounting and Public Policy, 28(4), 349-365. http://dx.doi.org/10.1016/j.jaccpubpol.2009.06.004

Koonce, L., McAnally, M., \& Mercer, M. (2005). How do investors judge the risk of financial items? The Accounting Review, 80(1), 221-241. http://dx.doi.org/10.2308/accr.2005.80.1.221

Lee, Y., Petroni, K., \& Shen, M. (2006). Cherry picking, financial reporting quality, and comprehensive income reporting choices: the case of property-liability insurers. Contemporary Accounting Research, 23(3), 665-700. http://dx.doi.org/10.1506/5QB8-PBQY-Y86L-DRYL

Lucier, C., Schuyt, R., \& Handa, J. (2004). CEO Succession 2003: The Perils of "Good"Governance. McLean, VA: Booz Allen Hamilton. 
Maines, L., \& McDaniel, L. (2000). Effects of comprehensive-income characteristics on nonprofessional investors' judgments: the role of financial statement presentation format. The Accounting Review, 75(2), 179-207. http://dx.doi.org/10.2308/accr.2000.75.2.179

Nichols, D. C., \& Wahlen, J. M. (2004). How Do Earnings Numbers Relate to Stock Returns? A Review of Classic Accounting Research with Updated Evidence. Accounting Horizons, 18(4), $263-286$. http://dx.doi.org/10.2308/acch.2004.18.4.263

S\&P. (2012). S\&P $350 \quad$ Europe $\quad$ Index. $\quad$ Retrieved $\quad$ May $14 \quad$ from http://www.standardandpoors.com/indices/sp-europe-350/en/eu/?indexId=speur-350-eurff--p-reu---

Scott, W. R. (2009). Financial Accounting Theory (5th ed.). Pearson.

Watts, R. L., \& Zimmerman, J. L. (1989). Positive Accounting Theory. Englewood Cliffs, NJ: Prentice-Hall.

Weisbach, M. (1988). Outside directors and CEO turnover. Journal of Financial Economics, 20, $431-460$. http://dx.doi.org/10.1016/0304-405X(88)90053-0

Yen, A., Hirst, D., \& Hopkins, P. (2007). A content analysis of the comprehensive income exposure draft comment letters. Research in Accounting Regulation, 19, 53-79. http://dx.doi.org/10.1016/S1052-0457(06)19003-7 